\title{
Morpho-physiological effects of environmental stress on yield and quality of sweet corn varieties (Zea mays L.)
}

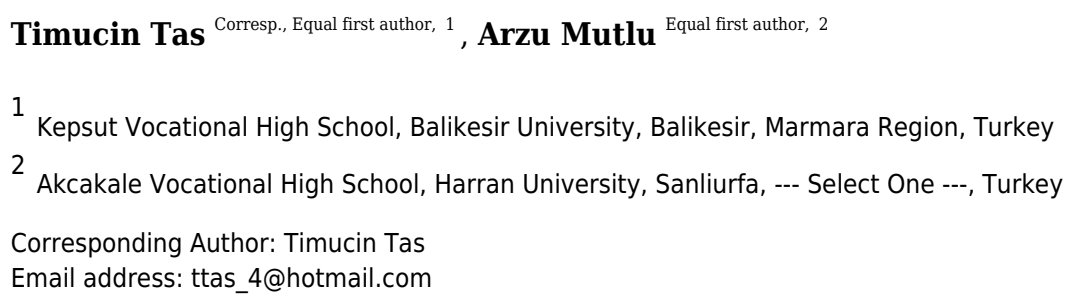

Sweet corn is cultivated in different climatic regions of the world, and consumed either fresh or processed. Morpho-physiological effects of environmental stress on yield, yield components and quality of some sweet corn varieties were investigated in field experiments conducted at Southeastern Anatolia Region of Turkey during 2019 and 2020 growing seasons. The experimental lay out was randomized blocks with 3 replicates. Eight candidates and 2 control sweet corn varieties classified as moderate maturity (FAO 650-700) were used in field experiment. Mean values of pollen fertility rate (PFR, \%), total soluble solids (TSS, OBrix), abscisic acid (ABA, nmol/g DW), ear length (EL, cm), plant height $(\mathrm{PH}, \mathrm{cm})$, number of grains per cob (CGN, grain) and fresh cob yield (FCY, $t \mathrm{ha}^{-1}$ ) were significantly different between years and sweet corn varieties. The PFR, TSS, ABA, EL, $\mathrm{PH}, \mathrm{CGN}$ and FCY ranged from 40.29-67.65\%, 13.24-20.09 brix, 7.74-21.04 nmol/g DW, 9.69-15.98 cm, 97.80-171.34 cm, 289.15-420.33 grain and 4.15-10.23 t ha ${ }^{-1}$ respectively. The FCY, yield components and PFR values in the second year that had a higher temperature and lower relative humidity were lower compared to the first year, while ABA and TSS values were higher in the second year. Statistically significant correlations were recorded between the parameters investigated except FCY and TSS. The FCY and other parameters of sweet corn varieties, which produced high ABA phytohormone, were high, and the ABA hormone significantly contributed to plant growth under stress conditions. The results revealed that the PFR physiological parameter and ABA hormone in the plants provide important information about stress level and stress tolerance level of the cultivars, respectively. Despite adverse environmental stress conditions, the FCY of ŞADA-18.7 variety, one of the candidate varieties, was higher than that of the control and the mean value of the experiment. 
4

5

6

7

8

9

10

11

12

13

14

15

16

17

18

19

20

21

22

23

24

25

26

27

28

29

30

31

32

33

34

35

36

37

38

39

40

41

42

43

44

45

46

47

\section{Morpho-physiological effects of environmental stress on yield and quality of sweet corn varieties (Zea mays L.)}

Timucin $\mathrm{TAS}^{1 *}$, Arzu MUTLU2

${ }^{1}$ Kepsut Vocational High School, Balikesir University, Kasapzade Neighborhood, 23 Burhan Alkan Street, Kepsut, Balikesir, Turkey, 10660 , +90 532709 31 40, thas_4@hotmail.com, Timucin TAS ORCID: https://orcid.org/0000-0002-2144-9064

${ }^{2}$ Department of Organic Agriculture, Akcakale Vocational High School, Harran University, Akcakale district, Sanliurfa, Turkey; arzu.usm@gmail.com Arzu MUTLU ORCID: https://orcid.org/0000-0001$\underline{\text { 8992-8371 }}$

Corresponding Author:

Timucin $\mathrm{TAS}^{1^{*}}$

Balikesir University, Kasapzade Neighborhood, 23 Burhan Alkan Street, Kepsut, Balikesir, Turkey

Email address: ttas_4@hotmail.com 


\title{
Morpho-physiological effects of environmental stress on yield and quality of sweet corn varieties (Zea mays L.)
}

\begin{abstract}
Sweet corn is cultivated in different climatic regions of the world and consumed either fresh or processed. Morpho-physiological effects of environmental stress on yield, yield components and quality of some sweet corn varieties were investigated in field experiments conducted in Southeastern Anatolia Region of Turkey during 2019 and 2020 growing seasons. The experimental lay out in both years were randomized blocks with 3 replicates. Eight candidates and 2 control sweet corn varieties classified as moderate maturity (FAO 650-700) were used in field experiment. Mean values of pollen fertility rate (PFR, \%), total soluble solids (TSS, 0Brix), abscisic acid (ABA, nmol/g DW), ear length (EL, cm), plant height (PH, cm), number of grains per cob (CGN, grain) and fresh cob yield (FCY, $t$ ha $^{-1}$ ) were significantly different between years and sweet corn varieties. The PFR, TSS, ABA, EL, PH, CGN and FCY ranged from 40.2967.65\%, 13.24-20.09 $\mathrm{brix}, 7.74-21.04 \mathrm{nmol} / \mathrm{gDW}, 9.69-15.98 \mathrm{~cm}, 97.80-171.34 \mathrm{~cm}, 289.15-$ 420.33 grain and 4.15-10.23 $\mathrm{t} \mathrm{ha}^{-1}$ respectively. The FCY, yield components and PFR values in the second year that had a higher temperature and lower relative humidity were lower compared to the first year of the experiment, while ABA and TSS values were higher in the second year. Statistically significant correlations were recorded between the parameters investigated except FCY and TSS. The FCY and other parameters of sweet corn varieties, which produced high ABA phytohormone, were high, and the ABA hormone significantly contributed to plant growth under stress conditions. The results revealed that the PFR physiological parameter and ABA hormone in the plants provide important information about stress level and stress tolerance level of the cultivars, respectively. Despite adverse environmental stress conditions, the FCY of ŞADA-18.7 variety, one of the candidate varieties, was higher than that of the control and the mean value of the experiment.
\end{abstract}

Key words: sweet corn, heat stress, pollen fertility, abscisic acid

\section{INTRODUCTION}

Sweet corn which is a type of maize harvested at the fresh stage and consumed as a vegetable. Sweet corn is belonging to family Poaceae and the genus Zea. Although sweet corn uses and accepts as a vegetable; maize, including sweet corn, is the third most important cereal crop after rice and wheat in the world. Smaller plant habitus and chemical composition of the grains are the distinguishing features of sweet corn from other corn types. The sugary1 (su1), shrunken2 (sh2), and sugary enhancer1 (se1 alleles) of sweet corn varieties prevent reduces the conversion of sucrose which is carried to the endosperm, to starch, and ensures that the grains have a high sugar content. The ratio of fat and protein is higher than other types of maize due to the larger relatively embryo of sweet corn (Szymanek, 2009).

Sweet corn is consumed before or after processing throughout the world. Unique taste, pleasant flavor and sweetness attracts the attentions of consumers. Sweet corn is also important for human nutrition due to positive contribution to health. In addition, high water (72.7\%) and total solids $(27.3 \%)$ contents of sweet corn kernels significantly contribute to the nutritional value. 
94 Furthermore, solid part contains hydrocarbons (81\%), proteins (13\%), lipids (3.5\%) and others $95(2.5 \%)$ (Ozata, 2019). Starch is the dominant hydrocarbon component of solid part (Szymanek, 96 2012). Calorie content of sweet corn kernel is moderate compared to the other vegetables. The

97

98 99

100

101

102

103

104

105

106

107

108

109

110

111

112

113

114

115

116

117

118

119

120

121

122

123

124

125

126

127

128

129

130

131

132

133

134

135

136

137

138

139 nutritional quality of sweet corn is also related to the dietary fiber, various vitamins, antioxidants, minerals, rich lutein, zeaxanthin and other carotenoids (Szymanek, 2012).

The sweet corn cultivation area in the world is about 1.6 million ha- ${ }^{1}$ with approximately 20 million tons production and average yield of $13.029 \mathrm{t} \mathrm{ha}^{-1}$ (Anonymous, 2020). Contracted farming model is widely applied for the production of sweet corn especially in Aegean, Marmara and the western part of Turkey; however, domestic production doesnot meet the demand of the country. Therefore, frozen-canned sweet corn import of Turkey in 2018 was approximately 7000 tons, which corresponds to approximately $\$ 9$ million, while the export potential of sweet corn is only \$ 0.85 million (Anonymous, 2018).

The adaptation of varieties to the ecological conditions of a region is important in selection of sweet corn varieties. Environmental factors which have adverse effects on plant growth and survival are known as abiotic stresses. The abiotic stress factors negatively affect the development of a plant, which adapted to any environment and grows smoothly (Abiko et al., 2005). High day and night time temperatures due to climate change threatens global agricultural production (Khaliq et al., 2019). Sweet corn is highly susceptible to environmental stress conditions compared to dent corn (Ordóñez et al., 2015). Several plant physiological and metabolic processes are adversely affected by heat stress, therefore heat stress is considered an important constraint to plant growth and crop productivity (Allakhverdiev et al., 2008). The responses of plants to abiotic stress factors vary depending on the amount of accumulation of phytohormones which modulate the physiological and molecular responses of plants to survive under abiotic stress conditions (Fahad et al., 2015). Absisic acid (ABA) is an important plant regulating hormone used to determine the tolerance of sweet corn plant to stress conditions (Islam et al., 2018), while, pollen vitality ratio also provides important clues about the stress levels of sweet corn plants. The ABA induces heat tolerance in corn (Islam et al., 2018). Similarly, Zandalinas et al. (2016) reported that ABA reduces the heat stress damage in sweet corn plants. Under heat and dry weather conditions, lack of ABA in corn plants increases water loss from stomata, therefore plants display heat stress-sensitive phenotypes ( $\mathrm{Du}$ et al., 2013). Heat stress tolerance of mutants defective in ABA signaling (abi1-1) or lack of ABA biosynthesis (aba1-1) is reported very low (Suzuki et al., 2016).

The optimum temperature for maize flowering occurrs between 25 and $35{ }^{\circ} \mathrm{C}$ (Sánchez et al., 2014). Furthermore, the optimum temperature for maximum maize grain yield is around $25{ }^{\circ} \mathrm{C}$. Although the temperature tolerance level of maize varieties varies among themselves, it has been reported that maize varieties experience high stress and struggle to survive at temperatures above $40{ }^{\circ} \mathrm{C}$ (Alam et al., 2017). Although the effect of temperature stress on number of grains in pretasseling period is not clear, high temperature in tasseling-silking interval leads to significant yield reduction (Lizasoa et al., 2018). Environmental factors such as fertility of soils, available water content, soil and air temperatures and relative humidity have significant effects on pollens production ability of plants; therefore, they impact the size and number of seeds produced. Pollens have $60 \%$ water content by weight; and, are sensitive to environmental conditions (Firon, Nepi \& Pacini, 2012). Environmental stress affects plant growth and even more 
140

drastically male reproductive development and causes to form sterile pollens (Begcy et al., 2019). The exposure of heat stress during micro gametogenesis cause abortion of microspores and male sterility (Rieu, Twell \& Firon, 2017; Begcy \& Dresselhaus, 2018). Alghabari et al. (2014) indicated that increased temperatures during the microspore stage of sweet corn pollens reduced corn cob fertility by affecting endogenous levels of ABA. Exposure of $35^{\circ} \mathrm{C}$ light and $25^{\circ} \mathrm{C}$ dark stress for $48 \mathrm{~h}$ specifically at pollination stage negatively affects gas exchange and chlorophyll content in addition to pollen fertility (Sunoj et al., 2017). Heat stress and low relative moisture humidity reduce pollen viability; thus they can be used to distinguish crop genotypes against various infield stresses (Razzaq et al., 2019). The seed yield is affected by the extreme temperatures. Temperatures greater than or equal to $32{ }^{\circ} \mathrm{C}$ are reported decreasing the viability of pollens, retention of pollens in the anthers and germination of pollens in various sweet corn varieties (Razzaq et al., 2017). High temperature during silking, pollination and grain filling profoundly affects pollen shedding and viability of sweet corn pollens Therefore, pollen viability and filled grains or number of grains under stress conditions have a positive correlation (Kalyar et al., 2013). The sugar content in kernels of sweet corn determines the quality of sweet corn (Szymanek, Tana's \& Kassar, 2015). Varieties, climate and harvest time have significant effects on sugar content of kernels (Abadi \& Sugiharto, 2019). Eating quality of final product is directly related to tenderness of sweet corn genotypes with a higher sugar and lower starch contents and an increased aroma (Ibrahim \& Ghada 2019). The sugar content of fresh kernels was reported higher compared to the frozen and canned grains (Alan et al., 2014).

Although sugar corn is a summer-growing plant and a total temperature requirement is between 10.000 and $12.000{ }^{\circ} \mathrm{C}$ during a growing season, sugar corn is stressed at temperatures above 35 ${ }^{\circ} \mathrm{C}$, resulting in losses in terms of yield, some agronomic and quality values (Tivari \& Yadav 2019). Sweet corn production which is mainly carried out in the western regions of Turkey, should be spread to the rest of the country to decrease sweet corn import and economic losses. Southern Turkey meets about $17 \%$ of dent corn production and is dominated by the high temperatures and dry weather conditions. Selection and breeding of sugar corn varieties that may successfully be grown in the southwest regions and tolerate high temperatures are highly important to expand the sugar corn production in Turkey. In this study, sweet corn varieties tolerant to environmental stress conditions were determined, and the relationship between physiological and biochemical responses of sugar corn varieties with fresh cob yield, some agronomic and quality characteristics were investigated.

\section{MATERIAL \& METHODS}

The study was conducted between June and November during the second crop corn season in 2019 and 2020. The experimental field was located in South Eastern Project Agricultural Research Institute, and lied between $36^{\circ} 44^{\prime} 10^{\prime \prime} \mathrm{N}$ latitudes and $38^{\circ} 50^{\prime} 20^{\prime \prime} \mathrm{E}$ longitudes (Figure 1).

\section{INSERT FIGURE 1}

\section{Soil and Climate characteristics of the Study area}

Soils of the experimental site have clayey texture, $\mathrm{pH}$ varies from 7.96 to 8.00 and electrical 
185

conductivity is between 1.05 and $1.40 \mathrm{dS} / \mathrm{m}$ which indicates no salinity problem Lime content is between 29.2 and $32.3 \%$ and increases with soil depth. Plant available phosphorus and organic matter contents were between $10.7-28.8 \mathrm{~kg} / \mathrm{ha}-1$ and $0.73-1.24 \%$, respectively.

The study area is located in a semi-arid climate zone with high temperatures and low relative humidity in summers. The temperature and relative humidity in the second year were significantly higher compared to the first year. The highest temperature recorded in June, July, August and September for both 2019 and 2020 was over $40{ }^{\circ} \mathrm{C}$ and relative humidity was less than $40 \%$. In the first year of the study, total precipitation during growing season was 27.8 $\mathrm{mm} / \mathrm{m}-2$, while it was only $0.4 \mathrm{~mm} / \mathrm{m}-2$ in the second year. Long term climate data indicated severe abiotic stress conditions such as high temperature and low relative humidity in the region. Current climate data revealed that, the amount of precipitation decreased and the semi-arid nature of the region has evolved into an arid region (Table 1).

\section{INSERT TABLE 1}

The average temperature during the 12-day top tasseling period in both years was over $40{ }^{\circ} \mathrm{C}$. Daily average temperature values in both years are shown in Figure 2.

\section{INSERT FIGURE 2}

\section{Experimental design and varieties traits}

Eight candidates and two control sweet corn varieties classified as moderate maturity (FAO 650700 ) were used in the study. The origins, grain colors and hybrid crosses of the varieties are shown in Table-2. The experiment was started at the second week of June in 2019 and 2020. Experimental lay out was randomized blocks with three replicates. Sweet corn seeds were planted in $70 \mathrm{~cm}$ interrow and $18 \mathrm{~cm}$ intrarow spacing. Each plot had 4 rows with $5 \mathrm{~m}$ length and total plot area was $14 \mathrm{~m}^{-2}$. Each plot had 110-115 plants.

\section{INSERT TABLE 2}

\section{Fertilization}

Fertilizer was applied in the seedbeds at rate of $400 \mathrm{~kg}$ ha- 1 in the form of diammonium phosphate $(18 \% \mathrm{~N}-46 \% \mathrm{P} 2 \mathrm{O} 5-0 \% \mathrm{~K} 20)$ during planting and the rest of the nitrogen $\left(400 \mathrm{~kg} \mathrm{~N}^{-}\right.$ $\left.{ }^{1}\right)$ was applied in the form of urea ( $46 \% \mathrm{~N}$ into two equal parts) at the second and thirteenth weeks of planting (Seydosoglu \& Cengiz, 2020).

\section{Irrigation}

Sprinkler irrigation method was used after planting to ensure a homogeneous seedgermination. Furrow irrigation method was applied in subsequent irrigations. The amount and number of irrigation during vegetation period varied depending on climate and water demand of plants. In the first year of the study, $600 \mathrm{~mm}$ of water was given in 5 irrigations, while in the second year $670 \mathrm{~mm}$ of water was given in 6 irrigations.

\section{Cobs harvest}


230 Fresh cobs were harvested between 17 and 25 September in both years of the trial. Harvest time 231 of varieties varied between 80 and 90 days. Fresh cobs were harvested when the grain moisture

\section{Analytical procedures}

Ten fresh cobs were collected from experiental plots, and the husks were peeled to determine the number of grains per cob (CGN, number), ear length (EL, cm), and fresh ear yield (FEY, $\mathrm{t} \mathrm{ha}^{-1}$ ) (Ibrahim \& Ghada, 2019).

\section{Total soluble solids (TSS, $\left.{ }^{\circ} \mathrm{Brix}\right)$}

Sweet corn kernels were squeezed out, and total soluble solids (TSS) content in sweet corn kernel juice was determined using a hand refractrometer $\left(0-32^{\circ}\right.$ Brix $)$. The TSS value of each cob was recorded, and the TSS value representing the sweet corn variety was determined by calculating the mean values (Alan et al., 2014).

\section{Pollen fertility rate (PFR, \%)}

Three tassels of each sweet corn variety were collected from each plot between 10:으 and 14:은 p.m. during tasseling development period when the anthers begin to dehisce. The samples of tassels were quickly transported to the laboratory in an ice. The pollens grains brought to the laboratory were placed on a glass lamella using a fine-tipped brush. A drop of 1\% TTC (2.3.5 Triphenyl Tetrazolium Chloride) liquid, which contained $0.2 \mathrm{~g}$ TTC and $12 \mathrm{~g}$ sucrose dissolved in $20 \mathrm{~mL}$ distilled water, was dropped on pollen samples, and the pollens were dyed within 2 to 3 hours. Pollen grains were counted under a light microscope to determine the viability rate of the dyed pollens. Pollen grains not dyed with TTC (dark red or brown color) were considered not viable, while pollen grains dyed with orange or bright red color were evaluated as viable (Sulusoglu \& Cavusoglu, 2014).

\section{Absisic acid (ABA, nmol/g DW)}

In the post-tassel emergence period, 10 flag leaves which were the last leaves to emerge in a cereal plant were sampled randomly in each plot. One hundred mg leaf sample was weighed and wrapped with aluminum foil and transported to the laboratory at $-198^{\circ} \mathrm{C}$ in a nitrogen tank. Leaf samples were stored in a refrigerator at $-20^{\circ} \mathrm{C}$. The $\mathrm{ABA}$ level of leaf samples was determined using Enzyme-Linked Immuno Sorbent Assay (ELISA) method (Cabot et al. 1986).

I) Preparation of the extraction buffer

To prepare the extraction buffer; $400 \mathrm{ml}$ of methanol (99\%) and 0.85 sodium bicarbonate (NaHCO3) were dissolved in deionized water and the final volume was adjusted to $100 \mathrm{ml}$. Five $\mathrm{mg}$ of butylated hydroxytoluene was added to a $100 \mathrm{mM} \mathrm{NaHCO} 3$ solution. Then, $400 \mathrm{ml}$ of methanol (99\%), $5 \mathrm{mg}$ of BTH and $100 \mathrm{mM} \mathrm{NaHCO} 3$ were mixed together and the final volume was adjusted to $500 \mathrm{ml}$. The $\mathrm{pH}$ of the extraction buffer was adjusted to 8.0 using $\mathrm{HCl}$ and stored at $40 \mathrm{C}$.

\section{I) Plant extraction stages}

Leaf samples in liquid nitrogen was ground in a mortar and $3 \mathrm{ml}$ of extraction buffer $(1.5 \mathrm{ml}+$ $1.5 \mathrm{ml}$ ) was added and homogenized. Homogenization was carried out in a dark environment. All samples were transferred to falcon tubes without leaving any herbal extract residue in the 
276

277

278

279

280

281

282

283

284

285

286

287

288

289

290

291

292

293

294

295

296

297

298

299

300

301

302

303

304

305

306

307

308

309

310

311

312

313

314

315

316

317

318

319

320

mortar. The homogenate was transferred to $15 \mathrm{ml}$ falcon tubes and incubated at $4{ }^{\circ} \mathrm{C}$ in the dark for 48 hours.

Homogenates in falcon tubes $(3 \mathrm{ml})$ were equally distributed with the pellets after 48 hours in 2 separate sterile $2 \mathrm{ml}$ ependorfs. All ependorfs were centrifuged at $4{ }^{\circ} \mathrm{C}$ for 30 minutes. Supernatants (upper liquid part) in ependorf tubes were transferred to $15 \mathrm{ml}$ clean falcon tubes and the 1 st supernatant was obtained. One $\mathrm{ml}$ of cold extraction buffer was added to the pellets remaining in the eppendorf. Following the vortexing, the solution was incubated in the dark for 24 hours at $4{ }^{\circ} \mathrm{C}$. Afterwards, incubated solution was centrifuged at $4{ }^{\circ} \mathrm{C}$ for 30 minutes and the second supernatant was obtained. The 2 nd supernatant was added to the falcon tubes containing the first supernatants and the final volumes in the falcon tubes were recorded in a table.

Heat block instrument was placed in a fume hood and ventilation was run. The temperature of the heat block was set to $45^{\circ} \mathrm{C}$. Each time, 12 falcon tubes were placed in the heat block and the liquid part was evaporated. The falcon tubes, whose liquid part was partially or completely evaporated, were closed and stored at $-20{ }^{\circ} \mathrm{C}$ until the ELISA test.

III) ABA reading stages

The chemicals and materials in the test kit consisted of standard $(64 \mathrm{nmol} / \mathrm{ml})$, standard dilution solution, ELISA micro plate (96 well), Str HRP conjugate reagent, 30X wash solution, biotin ABA, choromogen solution A, choromogen solution B, stop solution, plate closure membrane and sealed bags. The ABA solution $(64 \mathrm{nmol} / \mathrm{ml})$ in the ELISA KIT was diluted in 0, 2, 4, 8, 16 and $32 \mathrm{nmol} / \mathrm{ml}$ and standards were prepared. The $0 \mathrm{nmol} / \mathrm{ml}$ standard was set as a blank. The 50 $\mu \mathrm{L}$ of Streptavidin-HRP was pipetted into the standard wells of 96 -well micro plate, and $40 \mu \mathrm{L}$ of sample $+10 \mu \mathrm{L}$ of ABA antibody $+50 \mu \mathrm{L}$ of streptavidin-HRP was pipetted into the wells containing samples prepared by plant extraction.

After all wells were completed (empty wells were marked), the micro plate was covered with a membrane, gently shaken and incubated for 60 minutes at $37^{\circ} \mathrm{C}$. Meanwhile, $2.5 \mathrm{ml}$ of the washing solution was taken and diluted with $72.5 \mathrm{ml}$ of distilled water. The membrane covered on the micro plate was gently lifted and the liquids inside the plate drained. $350 \mu \mathrm{L}$ of the previously prepared washing solution was added to each well, and after 1-2 minutes, the plate in this solution was turned down and removed.

$50 \mu \mathrm{L}$ of choromogen $\mathrm{A}$ and $50 \mu \mathrm{L}$ of choromogen B were pipetted into all wells, including blanks, and gently shaken. The solutions were incubated for 10 minutes at $37^{\circ} \mathrm{C}$ in the dark. Then, $50 \mu \mathrm{L}$ of stop solution was added in all wells to stop the reaction. This step was performed when blue color in the wells turned into yellow. Auto zero was performed with the solution in the blank wells and the micro plate was placed into the reader. ABA values were obtained by reading the absorbance values at $450 \mathrm{~nm}$ with the Enzyme-Linked Immuno Sorbent Assay (ELISA KITS) method (Figure 3).

\section{INSERT FIGURE 3}

Statistical analysis 
321 Statistical analysis was performed using JUMP (Version 13.2.0) statistical software. Analysis of

322

323

324

325

326

327

328

329

330

331

332

333

334

335

336

337

338

339

340

341

342

343

344

345

346

347

348

349

350

351

352

353

354

355

356

357

358

359

360

361

362

363

364

365

366

variance including degrees of freedom and mean squares of all parameters in combined years was performed. The mean values for the varieties were compared using the LSD test at $p \leq 0.05$ probability level. Correlation test was performed between all traits determined in the study (Ucak et al., 2016).

\section{RESULTS}

The difference between years was statistically significant $(\mathrm{P} \leq 0.01)$ for $\mathrm{PFR}, \mathrm{ABA}$ and significant $(\mathrm{P} \leq 0.05)$ for $\mathrm{PH}, \mathrm{EL}, \mathrm{CGN}, \mathrm{TSS}$. The difference between varieties was statistically significant $(\mathrm{P} \leq 0.01)$ for all paremeters. The difference for PH, EL, CGN, FCY and PFR paremeters in year $\mathrm{x}$ variety interaction was not significant, while it was significant $(\mathrm{P} \leq 0.05)$ for TSS and $\mathrm{ABA}(\mathrm{P} \leq 0.01)$. Mean squares and degrees of freedom analysis of variance for yield and some traits of sweet corn varieties in combined years are shown in Table-3.

\section{INSERT TABLE 3}

Pollen fertility ratio (PFR), total soluble solids (TSS) and absisic acid (ABA) levels of sweet corn varieties.

The PFR and ABA parameters were significantly different $(\mathrm{P} \leq 0.01)$ between years and cultivars. The difference in TSS parameter was very significant $(\mathrm{P} \leq 0.01)$ between sweet corn varieties, while it was significant $(\mathrm{P} \leq 0.05)$ between the years (Table 4).

\section{INSERT TABLE 4}

The PFR parameter is one of the most important abiotic stress indicators for sweet corn varieties. The highest mean PFR value was obtained from Control-2 (67.65\%) sweet corn variety, while the lowest PFR value was obtained from ŞADA-18.2 (40.29\%) variety. The mean PFR in the first year was $55.80 \%$, while the mean PFR in the second year was $50.28 \%$. High temperature and low relative humidity values in the study area caused approximately $30-50 \%$ decrease in PFR values of sweet corn varieties. Daily average temperatures above $400 \mathrm{C}$ especially during 12-day of tasseling period negatively affected the pollen fertility. The results of correlation test indicated that the increase in PFR caused an increase in ABA level and yield components such as FCY, PH, EL and CGN.

The highest TSS value (20.09 ${ }^{\circ}$ brix) was recorded from the SADA-18.7 variety, and the lowest TSS value (13.24 obrix) was obtained from the Control-1 variety. The Obrix values of most sweet corn varieties were higher than the mean value of the experiment. High TSS values in sweet corn varieties are desired, but not yield losses. The TSS parameter had a negative correlation with PFR, FCY and yield components, while the TSS had a positive correlation with ABA.

The ABA level recorded in ŞADA-18.8 sweet corn candidate variety $(21.04 \mathrm{nmol} / \mathrm{g} \mathrm{DW})$ was higher than control and other varieties. Sweet corn varieties produced ABA hormone in both years of the study. The differences in environmental conditions (temperature and relative humidity) between years have also caused the differences in ABA levels. The results revealed that the amount of ABA hormone produced by sweet corn varieties varies depending on environmental stress conditions and genetic characteristics of the varieties. Positive correlation

Peer) reviewing PDF | (2021:05:61345:1:1:CHECK 21 Oct 2021) 
367

368

369

370

371

372

373

374

375

376

377

378

379

380

381

382

383

384

385

386

387

388

389

390

391

392

393

394

395

396

397

398

399

400

401

402

403

404

405

406

407

408

409

410

411

412

between $\mathrm{ABA}$ hormone and all other parameters indicates that the increase in $\mathrm{ABA}$ hormone causes an increase in FCY, yield components, PFR and TSS values of the sweet corn varieties.

\section{Some agronomic traits of sweet corn varieties}

The ear length (EL) and plant height (PH) values in 2019 and 2020 were statistically significant at $\mathrm{P} \leq 0.01$ level, while the difference between years was significant only at $\mathrm{P} \leq 0.05$ level (Table 5).

\section{INSERT TABLE 5}

The EL and PH parameters are important agronomic traits which may have direct or indirect relationship with fresh cob yield (FCY). The highest EL value was measured in ŞADA-18.7 $(14.28 \mathrm{~cm})$ candidate variety and Control-1 and control-2 varieties were placed in the same statistical group with ŞADA-18.7. The lowest EL values was recorded in ŞADA-18.1 $(6.76 \mathrm{~cm})$. Lower EL values in the second year can be attributed to the higher temperature and lower relative humidity values.

The mean PH value of sweet corn varieties in the second year was $122.78 \mathrm{~cm}$, while it was $141.69 \mathrm{~cm}$ in the first year. Similar to the EL parameter, PH values were also affected by differences in temperature and relative humidity between years. The highest $\mathrm{PH}$ value was recorded in Control-2 cultivar $(171.34 \mathrm{~cm})$, while the lowest PH value was measured in ŞADA18.2 cultivar $(97.80 \mathrm{~cm})$.

\section{Number of grains per cob and fresh cob yields of sweet corn varieties}

The differences in number of grains per cob (CGN) and FCY in both years of the experiment were statistically significant at $\mathrm{P} \leq 0.01$ level, and the differences between years were significant at $\mathrm{P} \leq 0.05$ level. Statistical groups of varieties and years in terms of CGN and FCY parameters and level of significance were given in Table 6 .

\section{INSERT TABLE 6}

The CGN parameter is an important yield component and is directly related to the yield. Similar to the other yield components, the CGN parameter was negatively affected by the extreme temperature and relative humidity values. The mean CGN value of sweet corn varieties in 2020 was 323.05 grains, when environmental stress conditions were dominant, the CGN was 359.38 grains in 2019. The highest CGN value during the experiment was obtained from ŞADA-18.7 (420.33 grains), while the lowest CGN value was recorded in ŞADA-18.2 (289.15 grains) sweet corn variety.

The results of yield components were in agreement with the results of FCY parameter. The highest FCY value was obtained in ŞADA-18.7 $\left(10.23 \mathrm{tha}^{-1}\right)$ candidate variety, and the lowest FCY value was recorded in ŞADA-18.2 $\left(4.15 \mathrm{tha}^{-1}\right)$ variety. The FCY values recorded in ŞADA-18.8, ŞADA-18.3 and ŞADA-18.7 candidate varieties were higher than the mean values of the experiment. The FCY value obtained in ŞADA-18.7 variety was higher than the control varieties. 
413

414

415

416

417

418

419

420

421

422

423

424

425

426

427

428

429

430

431

432

433

434

435

436

437

438

439

440

441

442

443

444

445

446

447

448

449

450

451

452

453

454

455

456

457

458

Some parameters measured in the study were significantly different between years. Daily average temperatures during the tasseling period were above $40{ }^{\circ} \mathrm{C}$, which decreased the pollen viability ratios by almost half. Low relative humidity ratios in the same period also had an impact on the decrease in pollen viability. The ABA and TSS values in 2020 were higher, while the FCY values were lower, due to higher temperature and lower relative humidity compared to the first year of the experiment. The mean values of PFR, ABA, TSS and FCY in both years were shown in Figure 4.

\section{INSERT FIGURE 4}

The images of normal and abnormal pollens were recorded during pollen examination under the light microscope. The light red and bright colored pollens in the image A are alive, while the mat and black pollens in the image B are not alive. Pollen images of ŞADA-18.7 sweet corn variety examined under light microscope are given in Figure 5.

\section{INSERT FIGURE 5Correlations}

All parameters of sweet corn varieties determined were subjected to correlation test. The results of correlation test including correlation coefficients and level of significance was given in Table 7. Significant positive correlations were recorded between EL and $\mathrm{PH}(\mathrm{r}=0.8162, \mathrm{p}<0.01), \mathrm{CGN}$ and $\mathrm{PH}(\mathrm{r}=0.8292, \mathrm{p}<0.01), \mathrm{CGN}$ and $\mathrm{EL}(\mathrm{r}=0.7154, \mathrm{p}<0.01), \mathrm{FCY}$ and $\mathrm{PH}(\mathrm{r}=0.8577, \mathrm{p}<0.01)$, FCY and EL $(\mathrm{r}=0.8666, \mathrm{p}<0.01), \mathrm{FCY}$ and CGN $(\mathrm{r}=0.8434, \mathrm{p}<0.01), \mathrm{PFR}$ and $\mathrm{PH}(\mathrm{r}=0.9128$, $\mathrm{p}<0.01)$, PFR and EL $(\mathrm{r}=0.7664, \mathrm{p}<0.01)$, PFR and CGN $(\mathrm{r}=0.7796, \mathrm{p}<0.01)$, PFR and FCY $(\mathrm{r}=0.7691, \mathrm{p}<0.01)$.

\section{INSERT TABLE 7}

\section{DISCUSSION}

Agronomic traits such as PH and EL are important parameters that provide information on FCY. Taller sweet corn plants have a higher number of leaves. Plants with higher number of leaves cary out more photosynthesis, which causes an increase in EL and FCY values. Similar to the FCY and CGN, the PH and EL values decreased in the second year when environmental stress conditions such as high heat and low relative humidity were more dominant. It is thought that the plant's nutrient and biomass accumulation were insufficient under heat stress, due to disruptions in vital plant activities such as stomal conductivity, photosynthesis efficiency, chlorophyll content in leaves and insufficient gas exchange. It could be said that there were decreases in parameters such as PH, CGN, EL and indirectly FCR, due to these problems in plants. Stress conditions such as high temperature and low relative humidity experienced during the trial years suppressed the growth of plants, as a result of this, vegetative stages of some plants were completed very fast, and thus healthy leaves could not be developed and healthy plant height did not occur. The characteristics of a variety and climate have significant impact on plant heights of sweet corn (Subaedah, Edy \& Mariana, 2021).

The highest correlation coefficients of the experiment were obtained between PH and FCY, CGN and EL. The sweet corn varieties with the tallest plants had high FCY, EL and CGN values. 
459

460

461

462

463

464

465

466

467

468

469

470

471

472

473

474

475

476

477

478

479

480

481

482

483

484

485

486

487

488

489

490

491

492

493

494

495

496

497

498

499

500

501

502

503

504

Positive correlation between PH and PFR and ABA indicated that sweet corn varieties with a good PH had high PFR and ABA values. The plant heights recorded in this study are in harmony with the plant heights $(130.83-171.67 \mathrm{~cm})$ of Subaedah et al. (2021), while they were lower than the plant heights $(170.8-197.8 \mathrm{~cm})$ reported by Ibrahim \& Ghada (2019).

Similar to the PH, EL parameter is a directly related yield component with FCY, PFR and CGN. The results indicated that EL values of the varieties with high pollen viability rates were also high, therefore the FCY value was also higher. The EL parameter had a negative correlation with TSS, while the EL had significantly positive correlations with other traits The FCY values of sweet corn varieties, which have a long cob size were also high. The EL values recorded are compatible with the findings of Kara (2011), while they are lower than the EL values reported by Ibrahim \& Ghada (2019) (16.2-21.4 cm). Genetic characteristics of the varieties and environmental stress conditions of the study played a determinant role in the EL values measured. Short cob sizes can be attributed to the decrease in photosynthes under stress conditions such as temperature and low relative humidity and insufficient production of nutrients in the leaves.

Positive correlation between CGN and PFR parameters in sweet corn varieties indicated that the CGN is an important parameter to assess the impacts of environmental factors on sweet corn. The results showed that the fertilization rates of sweet corn varieties were high when viable pollen numbers in the grains were high, and in that case, the number of grains formed on a cob were higher. The CGN and EL, PH, FCY and PFR parameters were highly correlated and a moderate positive correlation was recorded between CGN and ABA. The results revealed that PFR values, which are important physiological parameters, coincided with the CGN values of sweet corn varieties. Due to the high temperatures of over $40^{\circ} \mathrm{C}$ during the tassel flowering period of the sugar corn plants, the PFR values decreased between 30 and $50 \%$ in both trial years. In addition, it is assumed that the synchrony between the tasseling and silking of plants is disrupted. Consistent with our study, high heat stress at the reproduction phase negatively affects the physiology of plants like flower initiation, source-sink relationship, falling of pods, which ultimately decreases the number of grains (Cairns et al., 2013). Similar to our findings, Lizasoa et al. (2018) reported that the number of grains per cob in sweet corn varieties had a high correlation with yield and yield components. Harmony in our findings, Patel \& Mankad (2014) reported a significant correlation between high cob yield and pollen fertility of sweet corn varieties. Consistent with our findings, Lizasoa et al. (2018) observed a $42 \%$ decrease in grain weight per plant and $32 \%$ in pollen viability with the increases in day/night temperatures from $25 / 15$ to $35 / 15{ }^{\circ} \mathrm{C}$ during tasseling-silking interval period.

Although the FCR values changed between years, heat stress negatively affected the fresh cob yields in both years. The PFR values obtained in both years give us clues about the fresh cob yields. Furthermore, tissue injuries in leaves are predicted to adversely affect the rate of photosynthes during heat stress, which can cause leaf damage and increase leaf senescence that largely result in decreasing photosynthetic efficiency. It is assumed that decreasing photosynthetic rate also reduced other yield components, especially FCR.

TSS parameter is one of the determining quality parameters of sugar corn. stress conditions, especially high temperature, contributed positively to TSS values. Contrary to the yield and yield 
505

506

507

508

509

510

511

512

513

514

515

516

517

518

519

520

521

522

523

524

525

526

527

528

529

530

531

532

533

534

535

536

537

538

539

540

541

542

543

544

545

546

547

548

549

550

components, the TSS values in the grains of sweet corn varieties were higher in the second year when warmer and dry weather conditions prevailed compared to the first year of the experiment. Due to high temperature stress in the second year of the trial, plants cannot absorb the water lost through evapotranspiration through the roots, Insufficient water content at cellular level in plants caused an increase in the dry matter ratio, in other words TSS values. Environmental stress causes decrease in yield and yield components, while increase in TSS values. The changes in TSS values of sweet corn varieties may attributed to the genetic structure and environmental conditions such as temperature, sowing time and harvest time.

Similar to our findings, Ibrahim and Ghada (2019) reported that TSS contents of sweet corn hybrids ranged from 12.10 to $17.43{ }^{\circ}$ Brix. Alan et al. (2014) recorded higher TSS values (16.3 to $27.4^{\circ}$ Brix) in kernels of seven sweet corn varieties. The results of Subaedah et al. (2021), which reported that the TSS values of sweet corn varieties varied between 20.8-22.8 ${ }^{\circ}$ Brix under Indonesian conditions, are substantially similar to those obtained in this study. The researchers associated the changes in TSS values to the differences in climate and variety.

ABA is a stress hormone that accumulates in leaves and roots, depending on the stress conditions and variety. The positive correlation between ABA and yield components indicates that the ABA hormone produced by plants promoted both lateral shoot and lateral root development; therefore, plants with strong roots and shoots grown healthier. The findings of Opitz et al. (2016) and Seeve et al. (2017) who reported that severe environmental stress inhibited both root and shoot growth but ABA promoted the formation of lateral roots and shoot, are in accordance with our conclusion. The results indicated that ABA hormone is an important selection criterion of sweet corn varieties or lines that are tolerant to environmental stress conditions. ABA plays a vital role in plants' physiological adjustments such as against heat stresses along with increasing seedling growth, endogenous levels of ABA and reduced oxidative damage to plants due to heat stress (Meena \& Yadav, 2015). Similar to our findings, the importance of ABA as a phytohormone involved in heat stress response and tolerance has been reported by Wasilewska et al. (2008) and Haizhen et al. (2018). In addition, Xu et al. (2013) indicated that ABA accumulates under stress conditions. In line with our study, several researchers had suggested that the ABA is an important direct heat-tolerant selection criterion in crops (Iqbal et al.,2017). Tao \& Zhao (2010) indicated that Plant growth hormone such as ABA play important roles in strengthening heat tolerance in maize under high-temperature stress. ABA induces maize to produce heat shock proteins (HSPs), strengthening photosystem II (PSII) heat tolerance (Maestri et al., 2002). In another study conducted, an exogenous ABA increases the maize cell membrane antioxidant capacity to improve heat tolerance (Gong et al., 1997). Phytohormone such as ABA, have key roles in coordinating various signal transduction pathways in plant during the heat stress response has been reported by Wani et al. 2016. Hasanuzzaman et al. (2018) observed that ABA is a signaling molecule and also enhance the number of other signaling molecules such as nitric oxide for thermos-tolerance.

The values of physiological parameters such as PFR and ABA determined in this study are compatible with the FCY values. Significant positive correlations were obtained between FCY and yield components such as PH, EL and CGN and physiological parameter such as PFR. Moderate positive correlation was recorded between FCY and ABA, while a negative correlation was obtained between FCY and TSS. The researchers showed that yield and yield components were decreased under high temperature conditions. Sweet corn varieties grown in the 
551 experimental area where environmental stress conditions prevail presented a good performance 552 in terms of FCY. The responses of sweet corn varieties to environmental stress conditions and 553 genetic characteristics of the varieties can be related to the good performance.

554 Values of ŞADA-18.7 candidate sweet corn variety were better compared to the other varieties, 555 and the highest yield of the experiment was obtained from ŞADA-18.7 candidate variety. The 556 differences in the yield of the tested sweet corn varieties was related to the differences in genetic 557 potentials. Subaedah et al. (2021) also indicated that the variety and the climate conditions of the 558 exponential field have significant impact on growth and yield of sweet corn varieties. The high 559 yield of sweet corn varieties was supported by the number of grains per cob, as well as the ear 560 length. Therefore, higher number of grains per cob and a longer cob size cause to obtain higher yield per unit area (Khan, Khan \& Afzal, 2017). Ilker (2011) also indicated that the fresh cob yield value was positively correlated with the yield components. The findings are consistent with the results obtained by Ahmad et al. (2015) who showed that fresh ear yields of sweet corn had a significant positive correlation with CGN, PH, EL and yield components.

\section{CONCLUSIONS}

The results of the study indicated that pollen fertility is an important index of environmental stress. The PFR parameter has come to the fore as an important and practically usable selection criterion to determine the most suitable varieties under stress conditions. The ABA hormone has a significant role in regulating the tolerance level of plants to temperature stress conditions. The ABA hormone protects the plants against heat stress at the cellular level, in addition, the ABA hormone positively contributes to the yield components, especially FCY and PFR values. The ABA hormone level will provide important clues about the tolerance level and yield of the sweet corn varieties in breeding programs to be carried out under abiotic or biotic stress conditions in the future, or in adaptation studies to determine the appropriate variety for all regions in the world. In long-term breeding and adaptation programs, the ABA hormone level of sweet corn lines and varieties included in breeding programs should be determined to save time and labor. The results concluded that physiological parameters such as ABA and PFR will save time and labor in breeding programs and variety adaptation experiments carried out with multiple materials in areas with environmental stress such as high temperature and low relative humidity.

\section{ADDITIONAL INFORMATION AND DECLARATIONS}

\section{Funding}

This study was supported by General Directorate of Agricultural Research and Policies affiliated to Republic of Turkey Ministry of Agriculture and Forestry. This study was a part of the national corn breeding program.

\section{Competing Interests}

The authors declare there are no competing interests.

\section{REFERENCES}


596 Abadi W, Sugiharto AN. 2019. Uji keunggulan beberapa calon varietas hibrida jagung manis 597 (Zea mays L. var. saccharata). Journal Produksi Tanaman 7(5): 939-948. 598 http://protan.studentjournal.ub.ac.id/index.php/protan/article/view/1135

599 Abiko M, Akibayashi K, Sakata T, Kimura M. 2005. High temperature induction of male 600 sterility during barley (Hordeum vulgare L.) anther development is mediated by transcriptional 601 inhibition. Sex Plant Reprod 18: 91-100. https://doi.org/10.1007/s00497-005-0004-2

602 Ahmad Z, Waraich EA, Ahmad T, Ahmad R, Awan MI. 2015. Yield responses of maize as 603 influenced by supplemental foliar applied phosphorus under drought stress. International Journal 604 of Food and Allied Sciences 1(2): 45-55 http://DOI:10.21620/ijfaas.2015245-55

605 Alam MA, Seetharam K, Zaidi PH, Dineshc A, Vinayan, MT, Nath UK. 2017. Dissecting heat 606 stress tolerance in tropical maize (Zea mays L.). Field Crops Research 204 (2017): 110-119. 607 http://dx.doi.org/10.1016/j.fcr.2017.01.006

608 Alan O, Kinaci G, Kinacı E, Basciftci ZB, Sonmez K, Evrenosoglu Y, Kutlu I. 2014. Kernel 609 quality of some sweet corn varieties in relation to processing. Not K. Bot. Horti. Agrobo 42(2): 610 414-419 https://DOI:10.15835/nbha4229425

611 Alghabari F, Lukac M, Jones HE, Gooding MJ. 2014. Effect of Rht alleles on the tolerance of 612 wheat grain set to high temperature and drought stress during booting and anthesis. J Agron Crop 613 Science 200(1): 36-45. https://doi.org/10.1111/jac.12038

614 Allakhverdiev SI, Kreslavski VD, Klimov VV, Los DA, Carpentier R, Mohanty P. 2008. Heat 615 stress: an overview of molecular responses in photosynthesis. Photosynth Research 98(1616 3):541-550. https://10.1007/s11120-008-9331-0

617 Anonymous 2018. Turkish Statistical Institute, Sweet corn import and export statistics in Turkey. 618 (date accessed:05.01.2021). https://data.tuik.gov.tr/Bulten/Index?p=Crop-Production-202033737.

Anonymous 2020. Food and Agriculture Organization of the United Nations. Crop production of maizereen. (date accessed:12.12.2020). http://www.fao.org/faostat/en/\#data/QC.

Begcy K, Dresselhaus T. 2018. Epigenetic responses to abiotic stresses during reproductive development in cereals. Plant Reprod 31(4): 343-355. https://10.1007/s00497-018-0343-4 sterility in maize after transient heat stress during the tetrad stage of pollen development. American Society of Plant Biologists 181: 683-700. https://doi.org/10.1104/pp.19.00707 Cabot C, Poschenrieder CH, Barcelo JA. 1986. Rapid method for extraction and estimation of abscisic acid from plant tissue using high performance Liquid Chromatography. Journal of Liquid Chromatography \& Related Technologies 9(13): 2977-2986. https://doi.org/10.1080/01483918608074164

631 Cairns JE, Hellin J, Sonder AJL, MacRobert JF, Thierfelder C, Prasanna BM. 2013. 632 Adapting maize production to climate change in sub-Saharan Africa. Food Security 5:345. 633 https://10.1007/s12571-013-0256-X

634 Du H, Wu N, Chang Y, Li X, Xiao J, Xiong L. 2013. Carotenoid deficiency impairs ABA and 635 IAA biosynthesis and differentially affects drought and cold tolerance in rice. Plant Moleculer 636 Biology 83(4-5):475-488. https://10.1007/s11103-013-0103-7

637 Fahad S, Hussain S, Bano A, Saud S, Hassan S, Shan D, Khan FA, Khan F, Chen YT, Wu 638 C, Tabassum MA, Chun MX, Afzal M, Jan A, Jan MT, Huang JL. 2015. Potential role of 639 phytohormone and plant growth-promoting rhizobacteria in abiotic stresses: consequences for 640 changing environment. Environ Science Pollut Research 22(7):4907-4921. 641 https://10.1007/s11356-014-3754-2 
642 Firon N, Nepi M, Pacini E. 2012. Water status and associated processes mark critical stages in 643 pollen development and functioning. Annals Botany 7:1201-1214. 644 https://doi.org/10.1093/aob/mcs070

645 Gong M, Chen SN, Song YQ, Li ZG. 1997. Effect of calcium and calmodulin on intrinsic heat 646 tolerance in relation to antioxidant systems in maize seedlings. Australian Journal of Plant 647 Physiology 24:371-379. https://doi.org/10.1093/jexbot/52.355.341

648 Hasanuzzaman M, Gill SS, Fujita M. 2018. Physiological role of nitric accumulation of Indian mustard (Brassica juncea L.). Journal of Oilseed Brassica 9(1):72-76. https://doi.org/10.1007/978$\underline{1-4614-5001-6 \quad 11}$

Haizhen M, Can L, Zhaoxia L, Qijun R, Guangning X, Baomei W, Shuang F, Jinfang C, Juren Z. 2018. ZmbZIP4 Contributes to stress resistance in maize by regulating aba synthesis and root development. American Society of Plant Biologists 178: 753-770. https://doi.org/10.1104/pp.18.00436

Ibrahim AIA, Ghada AA. 2019. Evaluation of some sweet corn hybrids for agronomic traits and technological parameters under different planting dates. Journal of Food Sciences 6 (1): 49-63. https://DOI:10.21608/scuj.2019.67838

658

Ilker E. 2011. Correlation and path coefficient analyses in sweet corn. Turkish Journal of Field Crops 16(2): 105-107. http://www.field-crops.org/assets/pdf/product51338eaa05334.pdf Islam MR, Baohua F, Tingting C, Longxing T, Guanfu F. 2018. Role of abscisic acid in thermal acclimation of plants. Journal Plant Biology 61: 255-264. https://10.1007/s12374-017-0429-9

Iqbal A, Iqbal MA, Iqbal A, Zubair A, Muhammad M, Zahoor A, et al. 2017. Boosting forage yield and quality of maize (Zea mays L.) with multispecies bacterial inoculation in Pakistan. Phyton International Journal of Experimental Botany 86:84-88

Kalyar T, Rauf S, Teixeira SJA, Iqbal Z. 2013. Variation in leaf orientation and its related traits in sunflower (Helianthus annuus L.) breeding population under high temperature. Field Crop Research 150: 91-98. https://doi.org/10.1016/j.fcr.2013.06.007 Kara B. 2011. Fresh ear yield and growing degree-days of sweet corn in different sowing dates in southwestern anatolia region. Turkish Journal of Field Crops 16(2):166-171. https://www.researchgate.net/publication/286196848

Khan M, Khan K, Afzal S. 2017. Seed yield performance of different maize (Zea mays L.) genotypes under agro climate conditions of Haripur. International Journal of Environmental Sciences and Natural Resources 5(2): 1-6. http://dx.doi.org/10.19080/IJESNR.2017.05.555672 Khaliq A, Iqbal MA, Zafar M, Gulzar A. 2019. Appraising economic dimension of maize production under coherent fertilization in Azad Kashmir, Pakistan. Journal of Custos $e$ Agronegocio 15(2):243-253. https://www.researchgate.net/publication/334479214 Lizasoa JI, Ruiz-Ramosa M, Rodrígueza L, Gabaldon-Lealb C, Oliveirac JA, Loriteb IJ, Sáncheza D, Garcíad E, Rodrígueza A. 2018. Impact of high temperatures in maize: phenology and yield components. Field Crops Research 216(2):129-140. https://doi.org/10.1016/j.fcr.2017.11.013

682

683

Meena RS, Yadav RS. 2015. Yield and profitability of groundnut (Arachis hypogaea L) as influenced by sowing dates and nutrient levels with different varieties. Legume Research 38(6):791-797. http://10.18805/lr.v38i6.6725

686

Maestri E, Klueva N, Perrotta C. 2002. Molecular genetics of heat tolerance and heat shock proteins in cereals. Plant Molecular Biology 48:667-681. http://10.1023/A:1014826730024 
687 Ordóñez RA, Savin R, Cossani CM, Slafer GA. 2015. Yield response to heat stress as affected 688 by nitrogen availability in maize. Field Crop Research 183:184-203. 689 https://10.1016/j.fcr.2015.07.010

690 Opitz N, Marcon C, Paschold A, Malik WA, Lithio A, Brandt R, Piepho HP, Nettleton D, 691 Hochholdinger F. 2016. Extensive tissue-specific transcriptomic plasticity in maize primary roots 692 upon water deficit. Journal Expriment Botany 67(4):1095-1107. https://10.1093/jxb/erv453

693 Ozata E. 2019. Evaluation of fresh ear yield and quality performance in super sweet corn. Journal 694 of Life Sciences and Biotechnology 2(2): 80-94. https://doi.org/10.38001/ijlsb.566890

695 Patel RG, Mankad AU. 2014. In vitro pollen germination. International Journal of Science and 696 Research 3(5): 304-307. https://www.researchgate.net/publication/279178292

697 Razzaq MK, Rauf S, Shahzad M, Ashraf I, Shah F. 2017. Genetic analysis of pollen viability: 698 an indicator of heat stress in sunflower (Helianthus annuus L). Int. J. Innov. Appr. Agriculture 699 Research 1(1): 40-508. https://doi.org/10.29329/ijiaar.2017.100.5

700 Razzaq MK, Rauf S, Khurshid M, Iqbal S, Bhat JA, Farzand A, Riaz A, Xing G, Gai J. 2019. 701 Pollen viability an index of abiotic stresses tolerance and methods for the improved pollen 702 viability. Pakistan Journal of Agricultural Research, 32(4): 609-624. DOI 703 http://dx.doi.org/10.17582/journal.pjar/2019/32.4.609.6

704 Rieu I, Twell D, Firon N. 2017. Pollen development at high temperature: From acclimation to 705 collapse. Plant Physiol 173: 1967-1976. https://doi.org/10.1104/pp.16.01644

Sánchez B, Rasmussen A, Porter JR. 2014. Temperature and the growth and development of maize and rice: a review. Global Change Biology 20: 408-417. https://doi.org/10.1111/gcb.12389 Seeve CM, Cho IJ, Hearne LB, Srivastava GP, Joshi T, Smith DO, Sharp RE, Oliver MJ. 2017. Water-deficit-induced changes in transcription factor expression in maize seedlings. Plant Cell Environment 40(5): 686-701. https://10.1111/pce.12891

Seydosoglu S, Cengiz R, 2020. Evaluation of the effects of different sowing dates and FAO stage groups on yield and yield attributs of second cultivated season for silage corn varieties. Euroasia Journal of Mathematics-Engineering Natural and Medical Sciences 8 (2): 117-125. http://dx.doi.org/10.38065/euroasiaorg.28

Subaedah St, Edy E, Mariana K. 2021. Growth yield and sugar content of different varieties of sweet corn and harvest time. International Journal of Agronomy 2021(1): 1-7. https://doi.org/10.1155/2021/8882140

Sulusoglu M, Cavusoglu A. 2014. In vitro pollen viability and pollen germination in cherry laurel (Prunus laurocerasus L.). Hindawi Publishing Corporation The Scientific World Journal 2014:17. https://doi.org/10.1155/2014/657123

Sunoj VSJ, Somayanda IM, Chiluwal A, Perumal R, Prasad PVV, Jagadish SVK. 2017. Resilience of pollen and post-flowering response in diverse sorghum genotypes exposed to heat stress under field conditions. Crop Science 57:1658-1669. https://doi.org/10.2135/cropsci2016.08.0706

Suzuki N, Bassil E, Hamilton JS, Inupakutika MA, Zandalinas SI, Tripathy D, Luo Y, Dion E, Fukui G, Kumazaki A, Nakano R, Rivero RM, Verbeck GF, Azad RK, Blumwald E, Mittler R. 2016. ABA is required for plant acclimation to a combination of salt and heat stress. Plos One 11(1): e0147625. https://10.1371/journal.pone.0147625

Szymanek M. 2009. Influence of sweet corn harvest date on kernel quality. Research in Agricultural Engineering 55(1):10-17. https://doi.org/10.17221/13/2008-RAE 
731 Szymanek M. 2012. Processing of sweet corn, trends in vital food and control engineering. Ayman 732 Amer Eissa (Ed.). Intech. Available at http://www.intechopen.com/books/trends-invital-food-and733 control engineering/processing-of-sweet-corn

734 Szymanek M, Tana's W, Kassar FH. 2015. Kernel carbohydrates concentration in sugary-1, 735 sugary enhanced and shrunken sweet corn kernels. Agriculture and Agricultural Science Procedia 736 7(2): 260-264. https://10.1016/j.aaspro.2015.12.044

737 Tao F, Zhao Z. 2010. Adaptation of maize production to climate change in North China Plain: 738 Quantify the relative contributions of adaptation options. European Journal of Agronomy 33:103739 116. http://doi:10.1016/j.eja.2010.04.002

740 Tiwari YK, Yadav SK. 2019. High Temperature stress tolerance in maize (Zea mays L.): 741 physiological and molecular Mechanisms. Journal Plant Biology 62:93-102. 742 http://10.1007/s12374-018-0350-X

743 Ucak AB, Oktem A, Sezer C, Cengiz R, Inald B. 2016. Determination of arid and temperature 744 resistant sweet corn (Zea mays saccharata Sturt) lines. International Journal of Environmental \& 745 Agriculture Research 2(7): 79-88.

746 Wani SH, Kumar V, Shriram V, Sah SK. 2016. Phytohormones and their metabolic engineering 747 for abiotic stress tolerance in crop plants. Crop Journal 4(3):162-176. 748 https://doi.org/10.1016/j.cj.2016.01.010

749 Wasilewska A, Vlad F, Sirichandra C, Redko Y, Jammes F, Valon C, Frei dit Frey N, Leung 750 J. 2008. An update on abscisic acid signaling in plants and more. Molecular Plant 1(2): 198-217. 751 https://10.1093/mp/ssm022

752 Xu W, Jia L, Shi W, Liang J, Zhou F, Li Q, Zhang J. 2013. Abscisic acid accumulation 753 modulates auxin transport in the root tip to enhance proton secretion for maintaining root growth 754 under moderate water stress. New Phytol 197(1): 139-150. https://10.1111/nph.12004

Zandalinas SI, Balfagón D, Arbona V, Gómez-Cadenas A, Inupakutika MA, Mittler R. 2016. ABA is required for the accumulation of APX1 and MBF1c during a combination of water deficit

757

758 and heat stress. Journal of Experimental Botany 67(18):5381-5390. https://10.1093/jxb/erw299 


\section{Table $\mathbf{1}$ (on next page)}

Important climatic values of the trial location.

Climate data for long years has been added to the table-1 which includes climate data and Table-1 have been updated 
1 Table 1:

2 Important climatic values of the trial location.

\begin{tabular}{|c|c|c|c|c|c|c|c|c|c|c|c|c|c|c|c|}
\hline \multirow[t]{2}{*}{ Months } & \multicolumn{3}{|c|}{$\begin{array}{c}\text { Mean temperatures } \\
\left({ }^{\circ} \mathrm{C}\right)\end{array}$} & \multicolumn{3}{|c|}{$\begin{array}{c}\text { The highest } \\
\text { temperatures }\left({ }^{\circ} \mathrm{C}\right)\end{array}$} & \multicolumn{3}{|c|}{$\begin{array}{c}\text { The lowest } \\
\text { temperatures }\left({ }^{\circ} \mathrm{C}\right)\end{array}$} & \multicolumn{3}{|c|}{ Mean humidity (\%) } & \multicolumn{3}{|c|}{$\begin{array}{c}\text { Total precipitation } \\
\left(\mathrm{mm} / \mathrm{m}^{-2}\right)\end{array}$} \\
\hline & 2019 & 2020 & ALY & 2019 & 2020 & ALY & 2019 & 2020 & ALY & 2019 & 2020 & ALY & 2019 & 2020 & ALY \\
\hline May & 31.0 & 32.2 & 28.7 & 38.8 & 40.0 & 40.3 & 15.8 & 14.6 & 12.5 & 42.3 & 45.9 & 51.2 & 10.2 & 0.2 & 26.8 \\
\hline July & 38.9 & 41.6 & 38.8 & 42.2 & 44.7 & 46.8 & 21.9 & 24.1 & 18.0 & 35.7 & 31.1 & 33.7 & 0.2 & 0.0 & 2.0 \\
\hline August & 39.7 & 40.1 & 38.4 & 42.8 & 45.4 & 46.2 & 22.7 & 22.0 & 19.0 & 38.9 & 36.2 & 32.5 & 1.2 & 0.0 & 3.4 \\
\hline September & 35.5 & 38.3 & 34.0 & 38.6 & 43.4 & 43.9 & 17.7 & 19.7 & 13.0 & 40.0 & 42.3 & 29.9 & 0.0 & 0.2 & 4.6 \\
\hline October & 30.7 & 32.2 & 27.1 & 34.6 & 37.0 & 37.8 & 12.9 & 14.9 & 10.9 & 50.6 & 39.5 & 43.1 & 12.8 & 0.0 & 26.5 \\
\hline November & 22.6 & 24.1 & 18.7 & 26.5 & 28.1 & 30.8 & 6.9 & 10.9 & 1.1 & 47.2 & 43.3 & 52.8 & 2.6 & 0.0 & 45.1 \\
\hline Average & 33.6 & 35.2 & 31.5 & 37.9 & 40.4 & 41.4 & 16.7 & 18.2 & 12.8 & 41.3 & 38.9 & 39.9 & 27.8 & 0.4 & 112.7 \\
\hline
\end{tabular}

$3+$ ): ALY: Average for long years (1920-2020) 


\section{Table 2 (on next page)}

Table 2: Sweet corn varieties and their some charectiscs

we have added the new table containing the characteristics of the varieties as Table-2 
1 Table 2:

2 Sweet corn varieties and their some charectiscs

\begin{tabular}{|c|c|c|c|}
\hline Variety name & Sweet corn & Ear colour & Origin \\
\hline ŞADA-18.1 & super sweet (su x sh) & yellow & Turkey \\
\hline ŞADA-18.2 & super sweet (su x sh) & yellow & Turkey \\
\hline ŞADA-18.3 & super sweet (su x sh) & yellow & Turkey \\
\hline ŞADA-18.4 & super sweet (su x sh) & yellow & Turkey \\
\hline ŞADA-18.5 & super sweet (su x sh) & yellow & Turkey \\
\hline ŞADA-18.6 & super sweet (su x sh) & yellow & Turkey \\
\hline ŞADA-18.7 & super sweet (su x sh) & yellow & Turkey \\
\hline ŞADA-18.8 & super sweet (su x sh) & yellow & Turkey \\
\hline Control-1 & super sweet (su x sh) & yellow & USA \\
\hline Control-2 & super sweet (su x sh) & yellow & USA \\
\hline
\end{tabular}

3 


\section{Table 3(on next page)}

Table 3: Mean squares and degrees of freedom analysis of variance results on yield and some traits of sweet corn varieties in combined years

we have added new table containing more detailed statistical analysis as table-3 
1 Table 3:

2 Mean squares and degrees of freedom analysis of variance results on yield and some traits 3 of sweet corn varieties in combined years

\begin{tabular}{|c|c|c|c|c|c|c|c|c|}
\hline \multirow[t]{2}{*}{ Source } & \multirow[t]{2}{*}{ DF } & \multicolumn{7}{|c|}{ Mean squares } \\
\hline & & PH & EL & CGN & FCY & PFR & TSS & $\mathbf{A B A}$ \\
\hline Repetition (year) & 2 & 116.89560 & 5.77886 & 1048.98562 & 6.47530 & 9.28743 & 6.61809 & 1.49086 \\
\hline Year x Variety & 9 & $56.51974 \mathrm{~ns}$ & 2.37874 ns & $680.67828 \mathrm{~ns}$ & $0.65450 \mathrm{~ns}$ & $12.35434 \mathbf{n s}$ & $6.65239 *$ & $8.80407 * *$ \\
\hline Error & 38 & 80.47829 & 1.33520 & 504.59526 & 1.18801 & 7.24173 & 3.14695 & 2.87081 \\
\hline $\mathrm{CV}$ & & 6.78 & 9.00 & 6.58 & 15.17 & 5.07 & 10.35 & 11.03 \\
\hline \multicolumn{9}{|c|}{ 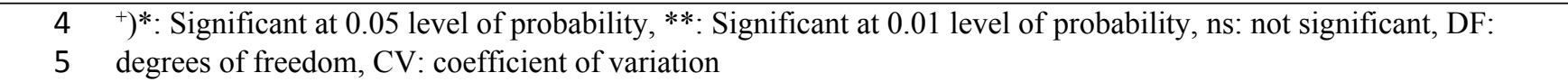 } \\
\hline \multicolumn{9}{|l|}{6} \\
\hline \multicolumn{9}{|l|}{7} \\
\hline
\end{tabular}




\section{Table 4 (on next page)}

Table 4: Pollen fertility and total soluble solids and absisic acid of sweet corn varieties in 2019 and 2020.

the performance of sweet corn varieties in terms of ABA, TSS and PFR. have showed in This table-4 
1 Table 4:

2 Pollen fertility and total soluble solids and absisic acid of sweet corn varieties in 2019 and 32020 .

\begin{tabular}{|c|c|c|c|c|c|c|c|c|c|}
\hline \multirow{2}{*}{ Varieties } & \multicolumn{3}{|c|}{ Pollen fertility rate (\%) } & \multicolumn{3}{|c|}{ Total soluble solids ( ${ }^{\circ}$ brix) } & \multicolumn{3}{|c|}{ Absisic acid (nmol $\left./ \mathrm{g}^{-1} \mathrm{DW}\right)$} \\
\hline & 2019 & 2020 & Mean & 2019 & 2020 & Mean & 2019 & 2020 & Mean \\
\hline ŞADA-18.1 & $44.33 \mathrm{f}$ & $38.48 \mathrm{~h}$ & $41.41 \mathrm{gh}$ & $17.32 \mathrm{abc}$ & $18.51 \mathrm{~cd}$ & $17.92 \mathrm{bc}$ & $8.04 \mathrm{f}$ & $12.11 \mathrm{ef}$ & $10.08 \mathrm{~g}$ \\
\hline ŞADA-18.2 & $45.51 \mathrm{ef}$ & $35.07 \mathrm{~h}$ & $40.29 \mathrm{~h}$ & $17.70 \mathrm{ab}$ & $20.15 \mathrm{bc}$ & $18.93 \mathrm{ab}$ & $5.67 \mathrm{f}$ & $9.81 \mathrm{f}$ & $7.74 \mathrm{~h}$ \\
\hline ŞADA-18.3 & $58.14 \mathrm{bc}$ & $55.22 \mathrm{~cd}$ & $56.68 \mathrm{~d}$ & $12.63 \mathrm{f}$ & $15.24 \mathrm{de}$ & $13.94 \mathrm{e}$ & $15.44 \mathrm{bcd}$ & $18.40 \mathrm{bc}$ & $16.92 \mathrm{~cd}$ \\
\hline ŞADA-18.4 & $46.22 \mathrm{ef}$ & $42.37 \mathrm{~g}$ & $44.29 \mathrm{~g}$ & $16.29 \mathrm{bcd}$ & $19.66 \mathrm{bc}$ & $17.98 \mathrm{bc}$ & $11.67 \mathrm{e}$ & $14.26 \mathrm{de}$ & $12.96 \mathrm{f}$ \\
\hline ŞADA-18.5 & $53.89 \mathrm{~cd}$ & $50.66 \mathrm{e}$ & $52.28 \mathrm{e}$ & $14.59 \mathrm{cdef}$ & $19.88 \mathrm{bc}$ & $17.24 \mathrm{bc}$ & $14.77 \mathrm{bcd}$ & $17.15 \mathrm{bcd}$ & $15.96 \mathrm{de}$ \\
\hline ŞADA-18.6 & $50.41 \mathrm{de}$ & $46.70 \mathrm{f}$ & $48.56 \mathrm{f}$ & $14.41 \mathrm{def}$ & $18.33 \mathrm{~cd}$ & $16.37 \mathrm{~cd}$ & $12.79 \mathrm{de}$ & $15.78 \mathrm{~cd}$ & $14.28 \mathrm{ef}$ \\
\hline ŞADA-18.7 & $61.44 b$ & $58.55 \mathrm{bc}$ & $60.00 \mathrm{c}$ & 15.70 bcde & $24.47 \mathrm{a}$ & $20.09 \mathrm{a}$ & 14.33 cde & $24.11 \mathrm{a}$ & $19.22 \mathrm{ab}$ \\
\hline ŞADA-18.8 & $57.36 \mathrm{bc}$ & $52.93 \mathrm{de}$ & $55.15 \mathrm{de}$ & $13.37 \mathrm{ef}$ & $16.15 \mathrm{de}$ & $14.76 \mathrm{de}$ & $19.42 \mathrm{a}$ & $22.67 \mathrm{a}$ & $21.04 \mathrm{a}$ \\
\hline Control-1 & $68.85 \mathrm{a}$ & $59.37 \mathrm{~b}$ & $64.11 \mathrm{~b}$ & $11.91 \mathrm{f}$ & $14.56 \mathrm{e}$ & $13.24 \mathrm{e}$ & $17.14 \mathrm{ab}$ & $19.59 \mathrm{~b}$ & $18.37 \mathrm{bc}$ \\
\hline Control-2 & $71.81 \mathrm{a}$ & $63.48 \mathrm{a}$ & $67.65 \mathrm{a}$ & $19.45 \mathrm{a}$ & $22.34 \mathrm{ab}$ & $20.90 \mathrm{a}$ & $16.82 \mathrm{abc}$ & $17.34 \mathrm{bc}$ & $17.08 \mathrm{~cd}$ \\
\hline Mean** & $55.80 \mathrm{a}$ & $50.28 \mathrm{~b}$ & 53.04 & $15.34 \mathrm{~b}$ & $18.93 \mathrm{a}$ & 17.13 & $13.61 \mathrm{~b}$ & $17.12 \mathrm{a}$ & 15.37 \\
\hline CV (\%) & 5.34 & 4.17 & 5.07 & 10.90 & 10.34 & 10.35 & 11.67 & 10.41 & 11.03 \\
\hline $\operatorname{LSD}(0.05)$ & $5.11^{* *}$ & $3.59 * *$ & $3.15^{* *}$ & $2.87 * *$ & $3.36^{* *}$ & $2.07 * *$ & $2.72 * *$ & $3.06^{* *}$ & $1.98 * *$ \\
\hline Mean LSD & & $3.39 * *$ & & & $2.86^{*}$ & & & $1.36^{* *}$ & \\
\hline
\end{tabular}

$\left.4{ }^{+}\right)$The means indicated with the same letter in the same column are not significantly different according to the JUMP 5 test at $\mathrm{P} \leq 0.05,{ }^{++}$) The means indicated with the same capital letter in the same row are not significantly different at $6 \mathrm{P} \leq 0.05$

$7{ }^{+++}$) The means of different year-varieties combinations with the same lower case letters are not significantly 8 different according to the JUMP test at $\mathrm{P} \leq 0.05$ 


\section{Table 5 (on next page)}

Table 5: Agronomic traits performance of sweet corn varieties in 2019 and 2020.

the performance of sweet corn varieties in terms of EL and PH. have showed in table-5 
1 Table 5:

2 Agronomic traits performance of sweet corn varieties in 2019 and 2020.

\begin{tabular}{lllllll}
\hline \multirow{2}{*}{ Varieties } & \multicolumn{3}{c}{ Ear length (cm) } & \multicolumn{3}{c}{ Plant height (cm) } \\
\cline { 2 - 7 } & $\mathbf{2 0 1 9}$ & $\mathbf{2 0 2 0}$ & Mean & $\mathbf{2 0 1 9}$ & $\mathbf{2 0 2 0}$ & Mean \\
\hline ŞADA-18.1 & $12.62 \mathrm{ef}$ & $6.76 \mathrm{e}$ & $9.69 \mathrm{e}$ & $107.90 \mathrm{~h}$ & $93.33 \mathrm{gh}$ & $100.62 \mathrm{~h}$ \\
ŞADA-18.2 & $12.15 \mathrm{f}$ & $9.20 \mathrm{~d}$ & $10.68 \mathrm{de}$ & $111.90 \mathrm{gh}$ & $83.70 \mathrm{~h}$ & $97.80 \mathrm{~h}$ \\
ŞADA-18.3 & $15.21 \mathrm{bc}$ & $11.87 \mathrm{bc}$ & $13.54 \mathrm{~b}$ & $152.79 \mathrm{~cd}$ & $138.30 \mathrm{bc}$ & $145.54 \mathrm{~cd}$ \\
ŞADA-18.4 & $13.36 \mathrm{def}$ & $7.98 \mathrm{de}$ & $10.67 \mathrm{de}$ & $121.90 \mathrm{fg}$ & $103.63 \mathrm{fg}$ & $112.77 \mathrm{~g}$ \\
ŞADA-18.5 & $14.22 \mathrm{~cd}$ & $10.09 \mathrm{~cd}$ & $12.15 \mathrm{c}$ & $129.57 \mathrm{ef}$ & $114.48 \mathrm{ef}$ & $122.02 \mathrm{fg}$ \\
ŞADA-18.6 & $13.77 \mathrm{cde}$ & $8.65 \mathrm{de}$ & $11.21 \mathrm{~cd}$ & $136.90 \mathrm{e}$ & $120.78 \mathrm{de}$ & $128.84 \mathrm{ef}$ \\
ŞADA-18.7 & $17.69 \mathrm{a}$ & $14.28 \mathrm{a}$ & $15.98 \mathrm{a}$ & $168.56 \mathrm{~b}$ & $148.52 \mathrm{ab}$ & $158.54 \mathrm{~b}$ \\
ŞADA-18.8 & $14.68 \mathrm{~cd}$ & $12.72 \mathrm{ab}$ & $13.70 \mathrm{~b}$ & $141.90 \mathrm{de}$ & $129.41 \mathrm{~cd}$ & $135.65 \mathrm{de}$ \\
Control-1 & $17.16 \mathrm{a}$ & $13.79 \mathrm{ab}$ & $15.48 \mathrm{a}$ & $158.56 \mathrm{bc}$ & $139.85 \mathrm{bc}$ & $149.21 \mathrm{bc}$ \\
Control-2 & $16.55 \mathrm{ab}$ & $13.76 \mathrm{ab}$ & $15.16 \mathrm{a}$ & $186.90 \mathrm{a}$ & $155.78 \mathrm{a}$ & $171.34 \mathrm{a}$ \\
\hline Mean** & $14.74 \mathrm{a}$ & $10.91 \mathrm{~b}$ & 12.82 & $141.69 \mathrm{a}$ & $122.78 \mathrm{~b}$ & 132.24 \\
\hline CV $(\%)$ & 5.96 & 12.47 & 9.00 & 5.53 & 5.99 & 6.78 \\
LSD (0.05) & $1.51 * *$ & $2.33 * *$ & $1.35 * *$ & $13.45 * *$ & $12.61 * *$ & $10.49 * *$ \\
Mean LSD & & $2.67 *$ & & & $12.01 *$ & \\
\hline
\end{tabular}

$3{ }^{+}$)The means indicated with the same letter in the same column are not significantly different according to the JUMP

4 test at $\mathrm{P} \leq 0.05,{ }^{++}$) The means indicated with the same capital letter in the same row are not significantly different at $5 \quad \mathrm{P} \leq 0.05$

$6^{+++}$) The means of different year-varieties combinations with the same lower case letters are not significantly 7 different according to the JUMP test at $\mathrm{P} \leq 0.05$ 


\section{Table 6(on next page)}

Table 6: A number of grains/per cob and fresh cob yield of sweet corn varieties in 2019 and 2020.

Important parameters such as FCY and CGN have been shown in Table-6 
1 Table 6:

2 A number of grains/per cob and fresh cob yield of sweet corn varieties in 2019 and 2020.

\begin{tabular}{lllllll}
\hline \multirow{2}{*}{ Varieties } & \multicolumn{3}{c}{ A number of grains/per cob (grain) } & \multicolumn{3}{c}{ Fresh cob yield (t ha $\left.\mathbf{~}^{-1}\right)$} \\
\cline { 2 - 7 } & $\mathbf{2 0 1 9}$ & $\mathbf{2 0 2 0}$ & Mean & $\mathbf{2 0 1 9}$ & $\mathbf{2 0 2 0}$ & Mean \\
\hline ŞADA-18.1 & $299.07 \mathrm{~g}$ & $295.00 \mathrm{bcd}$ & $297.04 \mathrm{e}$ & $6.64 \mathrm{ef}$ & $4.13 \mathrm{ef}$ & $5.38 \mathrm{fg}$ \\
ŞADA-18.2 & $312.52 \mathrm{fg}$ & $265.78 \mathrm{~d}$ & $289.15 \mathrm{e}$ & $5.49 \mathrm{f}$ & $2.82 \mathrm{f}$ & $4.15 \mathrm{~g}$ \\
ŞADA-18.3 & $367.07 \mathrm{bc}$ & $314.78 \mathrm{bcd}$ & $340.93 \mathrm{bc}$ & $9.40 \mathrm{bc}$ & $6.86 \mathrm{c}$ & $8.13 \mathrm{~cd}$ \\
ŞADA-18.4 & $328.25 \mathrm{ef}$ & $322.63 \mathrm{~b}$ & $325.44 \mathrm{~cd}$ & $7.39 \mathrm{def}$ & $5.20 \mathrm{de}$ & $6.29 \mathrm{ef}$ \\
ŞADA-18.5 & $354.22 \mathrm{~cd}$ & $301.29 \mathrm{bcd}$ & $327.76 \mathrm{~cd}$ & $8.26 \mathrm{cde}$ & $4.92 \mathrm{de}$ & $6.59 \mathrm{ef}$ \\
ŞADA-18.6 & $339.44 \mathrm{de}$ & $271.23 \mathrm{~cd}$ & $305.33 \mathrm{de}$ & $7.66 \mathrm{cde}$ & $3.46 \mathrm{f}$ & $5.56 \mathrm{f}$ \\
ŞADA-18.7 & $428.37 \mathrm{a}$ & $412.29 \mathrm{a}$ & $420.33 \mathrm{a}$ & $11.34 \mathrm{a}$ & $9.11 \mathrm{a}$ & $10.23 \mathrm{a}$ \\
ŞADA-18.8 & $353.59 \mathrm{~cd}$ & $317.30 \mathrm{bc}$ & $335.44 \mathrm{bc}$ & $8.63 \mathrm{bcd}$ & $5.99 \mathrm{~cd}$ & $7.31 \mathrm{de}$ \\
Control-1 & $378.11 \mathrm{~b}$ & $337.41 \mathrm{~b}$ & $357.76 \mathrm{~b}$ & $10.21 \mathrm{ab}$ & $7.13 \mathrm{bc}$ & $8.67 \mathrm{bc}$ \\
Control-2 & $433.15 \mathrm{a}$ & $392.78 \mathrm{a}$ & $412.97 \mathrm{a}$ & $10.49 \mathrm{ab}$ & $8.55 \mathrm{ab}$ & $9.52 \mathrm{ab}$ \\
\hline Mean** & $359.38 \mathrm{a}$ & $323.05 \mathrm{~b}$ & 341.21 & $8.55 \mathrm{a}$ & $5.82 \mathrm{~b}$ & 7.18 \\
\hline CV (\%) & 3.17 & 8.85 & 6.58 & 12.95 & 14.55 & 15.17 \\
LSD (0.05) & $19.53^{* *}$ & $49.07 * *$ & $26.25^{* *}$ & $1.90^{* *}$ & $1.45^{* *}$ & $1.27 * *$ \\
Mean LSD & $35.98^{*}$ & & & $2.83^{*}$ & & \\
\hline
\end{tabular}

$3{ }^{+}$)The means indicated with the same letter in the same column are not significantly different according to the JUMP

4 test at $\mathrm{P} \leq 0.05,{ }^{++}$) The means indicated with the same capital letter in the same row are not significantly different at $5 \quad \mathrm{P} \leq 0.05$

$6^{+++}$) The means of different year-varieties combinations with the same lower case letters are not significantly 7 different according to the JUMP test at $\mathrm{P} \leq 0.05$ 


\section{Table 7 (on next page)}

Table 7: Correlation coefficients and significance levels of yield components and grain yield and physiological parametre.

Correlative relations with each other of all parameters examined in the manuscript have been shown in table-7. 
1 Table 7:

2 Correlation coefficients and significance levels of yield components and grain yield and

3 physiological parametre.

Traits Traits Correlation Count The lowest $\quad$ The $\quad$ Significance $\quad$ Correlation levels coefficients coefficients highest levels (p)

(r) $\quad(95 \%)$ coefficients

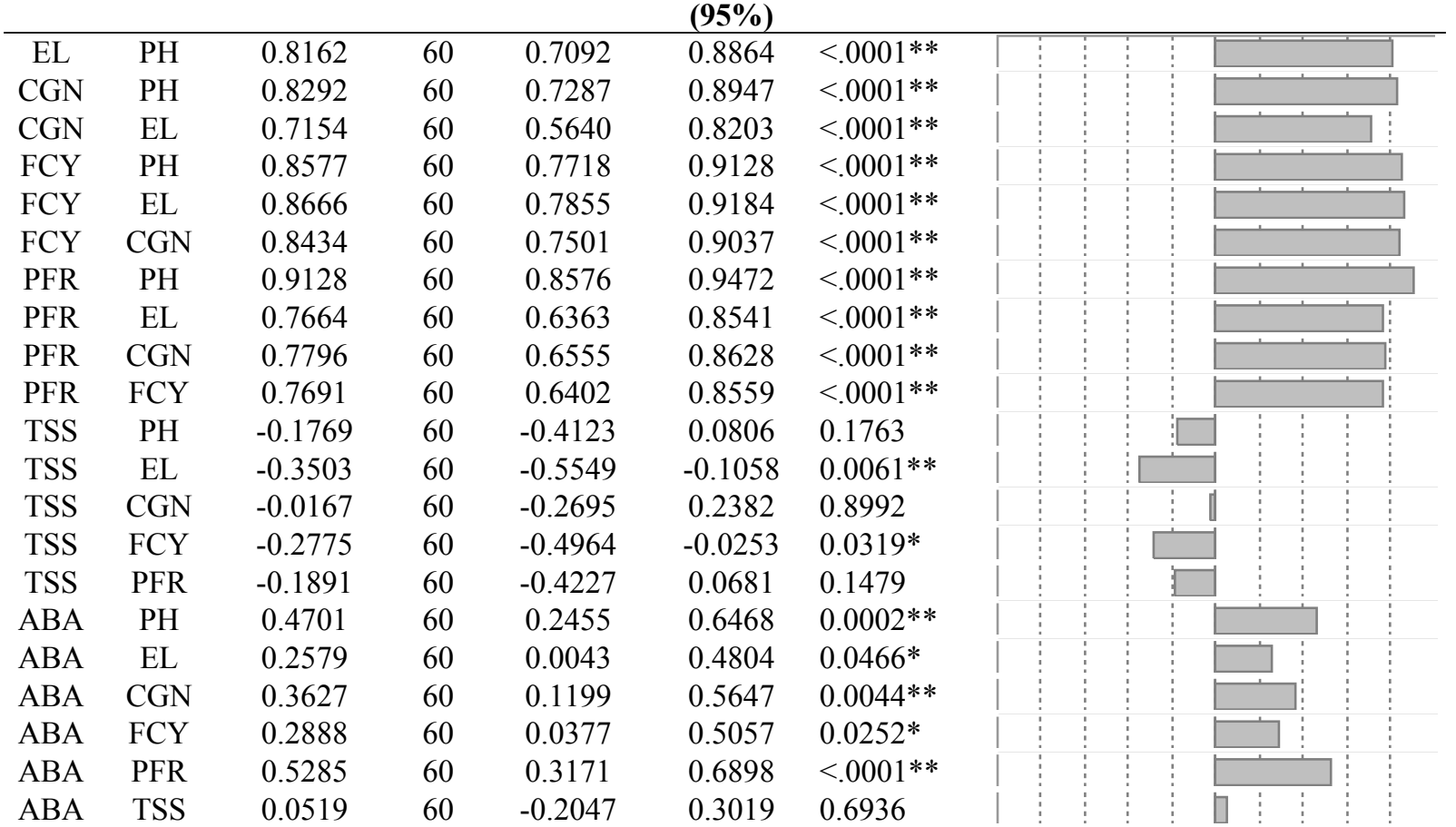

$\left.4{ }^{+}\right)$FCY: Fresh Cob Yield ( $\mathrm{t} \mathrm{ha}^{-1}$ ), CGN: Number of Grains/Per Cob (grain), PH: Plant Height (cm), EL: Ear Length

5 (cm), PFR: Pollen Fertility Rate (\%), TSS: Total Soluble Solids ( ${ }^{0}$ brix), ABA: Absisic Acid (nmol $\left./ \mathrm{g}^{-1} \mathrm{DW}\right)$

$\left.6{ }^{++}\right)^{*} . * *$ significant at 0.05 and 0.01 levels of probability. Respectively 


\section{Figure 1}

Figure 1: Geographical position of the study area.

The location having the hottest and driest climatic conditions on the Syrian border of Turkey was selected in both years of the experiment. Maps data: Google, @ 2021 CNES/Airbus, Maxar Technologies. 


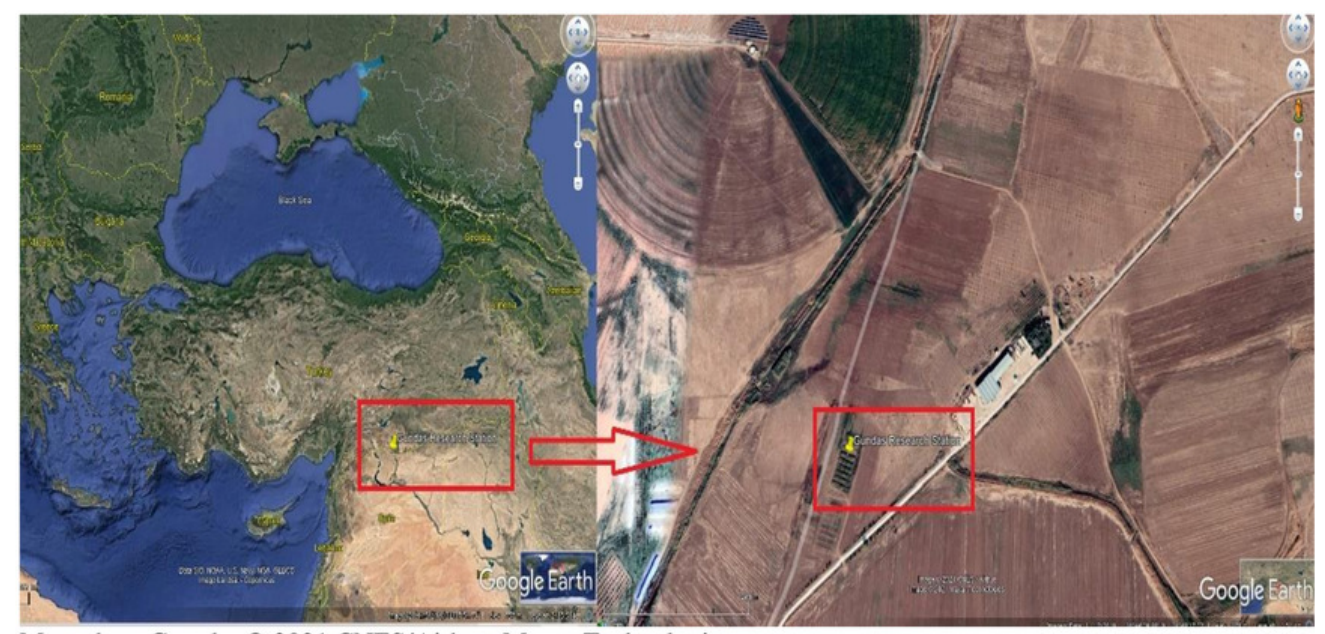

Maps data: Google, ( 2021 CNES/Airbus, Maxar Technologies 
Figure 2

Figure 2: Mean daily temperature values during the tasseling period in both years of the study.

The climate data used in the experiment were obtained daily from the climate station in the area where the experiment was conducted. 


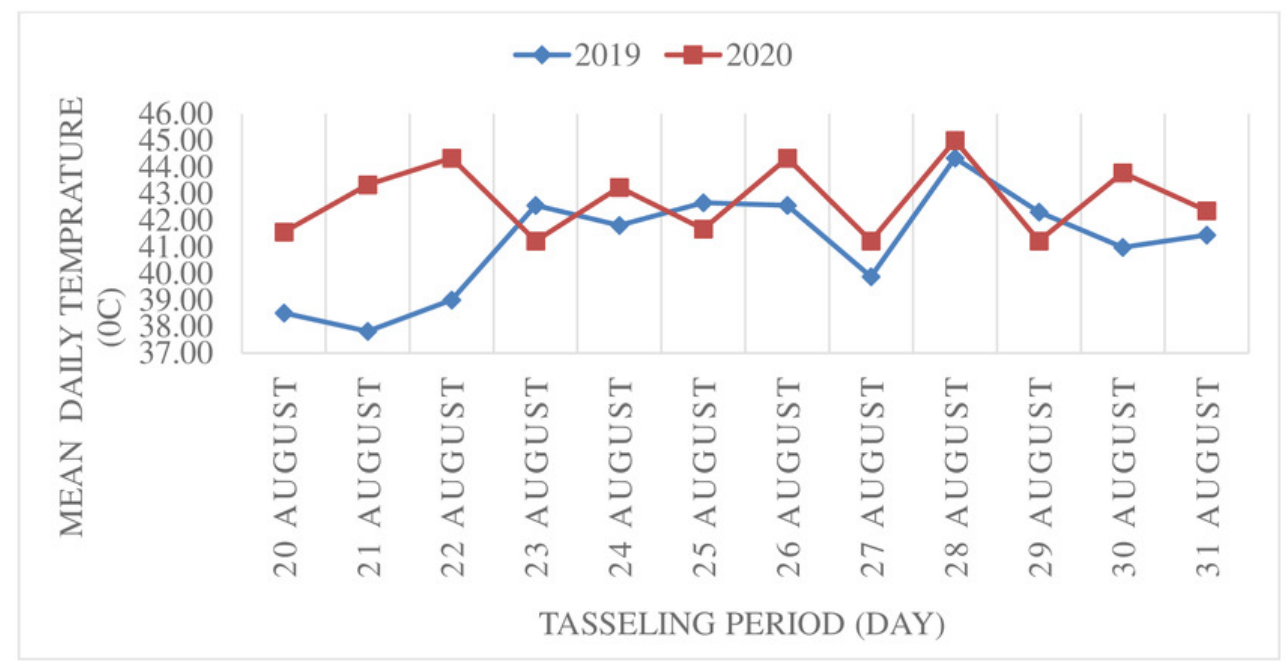


Figure 3

Figure 3: The ABA level of leaf samples was determined using Enzyme-Linked Immuno Sorbent Assay (ELISA)method

Stages such as homogenization process of $100 \mathrm{mg}$ leaf tissue (A) and transfer of homogenates to $15 \mathrm{ml}$ falcon tubes (B) and the falcon tubes with mixtures of 1st and 2nd supernatants (C) and microplate which is consisting of 96-well for ABA readings (D) of ABA analysis in sugar corn leaves. 


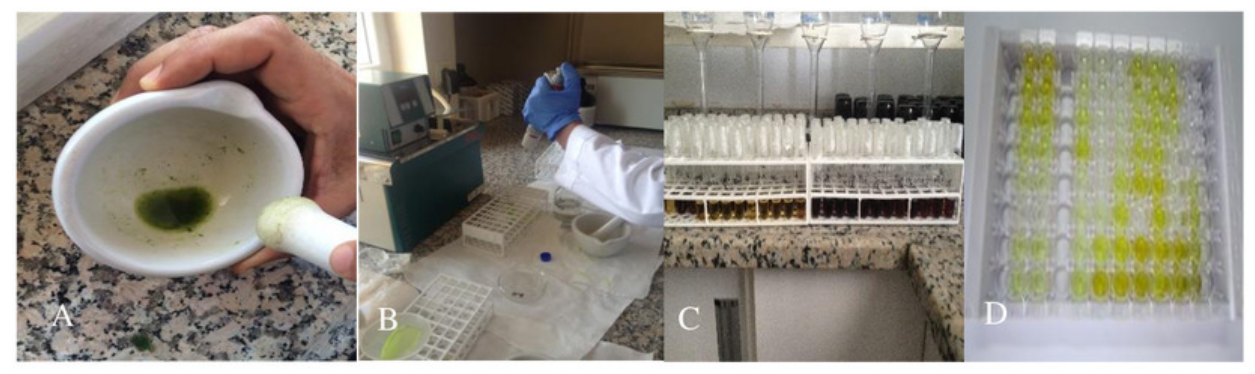




\section{Figure 4}

Figure 4:The mean values in both years of Some parameters such as polen fertility rate(PFR, \%), Absisic asit (ABA,nmol/g DW), Total soluble solids (TSS, ${ }^{\circ}$ brix) and Fresh cob yield $\left(F C Y, t h a^{-1}\right)(P \leq 0.05)$

The sweet corn varieties investigated in the study showed different physiological and biochemical responses under stress conditions such as severe temperature and low relative humidity. 


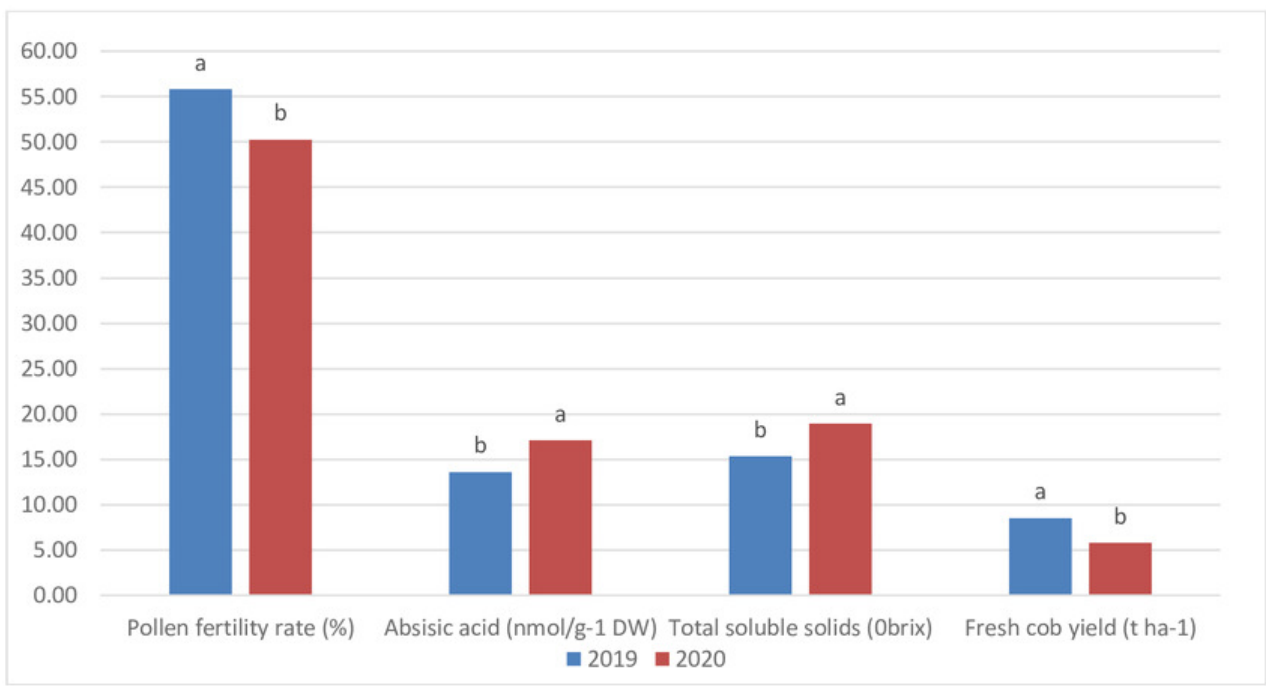




\section{Figure 5}

Figure 5: Pollen fertility (A) and pollen infertility (B) images of ŞADA-18.7 from sweet corn varieties under light microscope.

Pollen grains were counted under a light microscope to determine the viability rate of the dyed pollens. Pollen grains not dyed with TTC (dark red or brown color) were considered not viable, while pollen grains dyed with orange or bright red color were evaluated as viable 


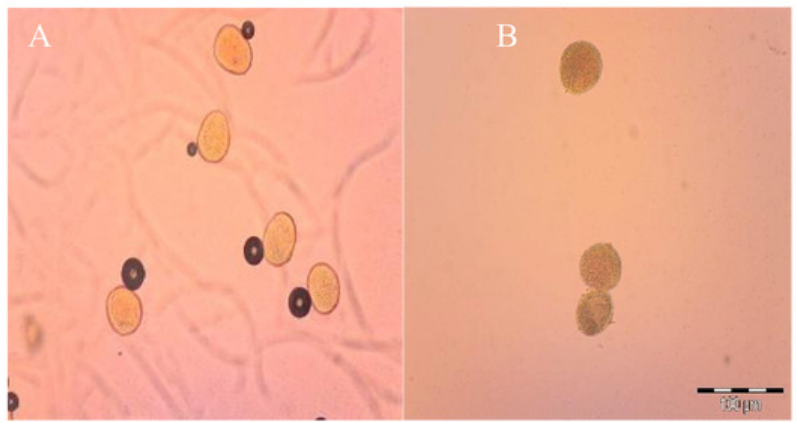

